\title{
ORGANIZATIONAL AND UNION CITIZENSHIP BEHAVIOR: ARE THEY UNILATERAL OR MULTILATERAL IN SRI LANKAN PUBLIC SECTOR CONTEXT
}

\author{
K. A. S. DHAMMIKA \\ Department of Human Resource Management \\ University of Kelaniya, \\ Sri Lanka \\ kasdhammika@yahoo.com
}

\begin{abstract}
Empirical studies on citizenship behavior of employees are largely centered on organizational citizenship behavior of employees. Other form of citizenship behavior of employees such as union citizenship has been identified. However, studies on citizenship behavior with a multilateral perspective are scant in behavioral studies and in Sri Lankan context in particular. The objective of this study is to examine whether organizational and union citizenship behavior are exhibited simultaneously by unionized employees in Sri Lanka. A sample of 200 employees was selected for this study from selected number of public sector organizations. A standard questionnaire was used to assess the organizational and union citizenship behavior of respondents. Bivariate correlation and model testing with structural equation modeling were applied for the analysis of the data. It was found that organizational and union citizenship behavior can be observable simultaneously among the respondents indicating a multilateral citizenship behavior. Further, it was revealed that the degree of coexistence of organizational and union citizenship behavior increases when the union tenure period of employees increases.
\end{abstract}

Keywords: Organizational Citizenship Behavior, Union Citizenship Behavior, Unionization of Employees.

\section{Introduction}

Studies on citizenship behavior of employees have largely concentrated on organizational citizenship behavior. However, there might be other form of citizenship behavior of employees in certain organizational context. Union citizenship behavior has been identified as a form of citizenship behavior associated with unionized employees (Twigg, Fuller \& 
Hester, 2008). It seems that researchers on citizenship behavior have explored union and organizational commitment of unionized employees with unilateral perspective. However, with the empirical evidence on possibility of mutual existence of citizenship behaviors, for instance, union and organizational commitment, it can examine whether the citizenship behaviors coexist. It is observed that studies on both organizational citizenship behavior and union citizenship behavior are scant in the field of behavioral studies. The purpose this study is to examine organizational and union citizenship behavior of unionized employees of the public sector organizations with multilateral perspective. That is whether they are mutually existed or not in Sri Lankan public sector organizational context.

\section{Organizational Citizenship Behavior}

Organizational Citizenship Behavior (OCB) has been one of the main topics that get practitioners and researchers attention and interests (Chang \& Chelladurai 2003). Organ (1988) defined organizational citizenship behavior as work related behaviors that are discretionary, not related to the formal organizational reward system, and in the aggregate, promote the effective functioning of the organization (Organ, 1990, p. 46). The main characteristic of the OCB is that employees engage in helping others' activities without expecting anything from them. Researchers have studied OCB as a unidemensional and multidimensional construct as well. However, most of them believe that OCB is a multidimensional construct. Accordingly, altruism and generalized compliance are such two dimensions (Naguni et al.,2004). Early conception of OCB by Organ (1988) had five dimensions namely, altruism, courtesy, conscientiousness, civic virtue, and sportsmanship. $\mathrm{He}$ further made a distinction between OCB behavior such as serving in committee voluntarily that benefits the organization (OCBO) and OCB that benefits the individuals in organization (OCBI). But later studies confirmed four dimensions: altruism, courtesy, peacekeeping, and cheerleading (Podsakoff \& MacKenzie, 1994). They further identified five dimensions of OCB as (1) altruism - employees help coworker with job relevant duties and tasks, (2) courtesy - being polite, considerate of others, and treat them with respect, (3) conscientiousness - when employee goes beyond normal requirements or expectations (4) sportsmanship employees have a positive attitude and are willing to tolerate less than ideal circumstances without complaining, and (5) civic virtue - participating in the governance of the organization. Several factors such as job satisfaction, justice, and support or trust from the organization and leaders were found to be determinants of OCB behavior of employees (Ackfeldt \& Coote, 2000). 
Several factors have been identified as possible antecedents of OCB (Bateman \& Organ, 1983). Among them, job satisfaction, organizational and procedural justice, organizational support and trust of the leader have been highlighted (Bateman \& Organ, 1983; Neihoff \& Moorman, 1993; Williams and Anderson, 1991). These factors prompt employees to engage in activities that are not within the scope of their job, but benefit the organization in broader sense.

The effects of OCB for both individual employee and organization have been revealed. It has highlighted that OCB improves the overall performance of employees, job satisfaction, and customer satisfaction ( Walz \& Niehoff, 2000).Furthermore, OCB is found to be associated with to high job performance, productivity, efficiency, cost reduction, profitability, employees' retention and customer satisfaction (Podsakoff, Whiting, Podsakoff, \& Blume, 2009). Therefore, improving OCB behavior of employees is contributory to the organizational effectiveness and efficiency at last.

\section{Union Citizenship Behavior}

Union Citizenship Behaviors (UCB's) are voluntary and contribute to the union's functions, but are not explicitly required or rewarded by the union (Twigg et al.,2008). They are activities of union members that would be considered going above and beyond the call of duty and that are not directly rewarded by the union (Skarlicki \& Latham, 1996). It is clear from these definitions that UCB is concept derived from the studies on organizational citizenship behavior. Accordingly, if member of a union exhibit an engagement in union activities that are not expected otherwise, they can be seen as UCB.

It was found that organizational justice in union increases the union citizenship behavior of their members. Further, Aryee and Chey (2001) claimed perceived union support and union instrumentality mediates the relationship between organizational justice and UCB. Union leaders training on organizational justice principles increases the UCB of the union member employees (Skarlicki \& Latham ,1996).

Union commitment is behavioral extension of the union support behavior of employees. Union citizenship behavior is largely determined by the degree of union commitment of employee and perceived union support. UCB such as participation in union activities, filing grievances, attending meetings, and voting behaviors are claimed be very important for the betterment of the unions (Barling, Fullagar, \& Kelloway, 1992). This is especially relevant to the context where participation in union activities by their members is gradually declining 
(Twigg et al., 2008). Therefore, union leader particularly should take actions to improve the $\mathrm{UCB}$ of their members so that they can mobilize more employees into their union activities.

\section{OCB and UCB}

Theoretical arguments are available in OCB and UCB literature that suggest possible coexistence of OCB and UCB though they are not empirically examined. One of the factors that make OCB and UCB multilateral is the work place justice. Workplace justice consists of distributive justice and procedural justice (Aryee \& Chay, 2001). Distributive justice represents the fairness of distribution of resource among members of the organization and the criteria used for that. On the other hand, procedural justice means fairness of the process and procedure in the organization (Floger \& Greenberg, 1995). Since employee union activities bears some implication for both distributive and procedural justice, for instance involving in grievances handling and disciplinary inquiries, union contributes to the distributive and procedural justice. Therefore, it can be argued that unionized employees may engage in organizational and union citizenship behavior simultaneously. Adding to this argument is the fact that transformational leadership behavior of leader will result in both OCB and UCB in organizations (Twigg et al., 2008). It is because transformational leadership behavior is perceived positively by unionized employees as union supportive behavior (Snape \& Redman, 2004). This will result in higher commitment of employees towards both the organization further leading to OCB and UCB. On these empirical grounds, it can reasonably argue that OCB and UCB can be multilateral in some context. Therefore, the present study hypothesized that

$\mathrm{H}_{1}$ : OCB and UCB are coexisted among the unionized employees of the public sector organizations.

\section{Methods and Procedure}

\section{Sample}

A sample of 200 employees from 10 public sector organizations was drawn for the purpose of data collection using simple random sampling method. Public sector employees were selected since they were reported to be highly unionized (Jinadasa \& Opatha, 1999). Demographic background of the respondents is such that $63 \%$ of them are male while $37 \%$ is female. Majority of them (67\%) have work experience of more than 10 years, while $16 \%$ and $17 \%$ of them has 5 to 10 years and less than 5 years of work experience. $78 \%$ of respondents is active 
member of unions for more than five years and the rest has been members of less than five year of membership period.

\section{Measurements}

Union citizenship behavior was assessed by using the five item instrument of Skarlicki and Latham (1996). Respondents were asked to rank behaviors on a scale ranging from one (not at all characteristic of me) to five (very characteristic of me). Reliability of the instrument was assessed with Cronbach's alpha coefficient (Alpha=.76; mean=2.11; Standard deviation=1.03). The validity of the instruments was assessed by the confirmatory factor analysis as first order factor structure. The results indicate that the hypothesized factor model provides the best fit to the data $(\chi 2=132.08, d f=5$, $\mathrm{RMSEA}=0.07)$.

Organizational Citizenship Behaviors was assessed with 24-items OCB scale developed by (Podsakoff, et al. 1990). This measurement assesses the five dimensions of OCB proposed by Organ (1988). These dimensions were altruism (5 items), conscientiousness (5 items), courtesy (5items), sportsmanship (5 items) and civic virtue (4 items). The responses were scaled from 1 (Strongly Disagree) to 5 (Strongly Agree). The reliability of this instrument was found to be high with Cronbach's Alpha value (Alpha=.86; mean=2.88). As with UCB instrument, the validity of OCB measure was assessed with CFA on its measurement model as second order factor structure. This is based on the fact that the five dimensions of OCB's are found to be valid in numerous studies. It recorded a satisfactory level of model fit sample data indicating its construct validity $(\chi 2=184.08, d f=5$, RMSEA=0.06).

\section{Data Analysis}

Preliminary correlation analysis was used to examine the association between organizational and union citizenship behavior of employees. However, Model testing was done using SEM, so that it can test whether the model can be equivalent across union employees with different union membership period. The model is a measurement model of OCB and UCB measuring the covariance between them. It is shown in the following figure. 


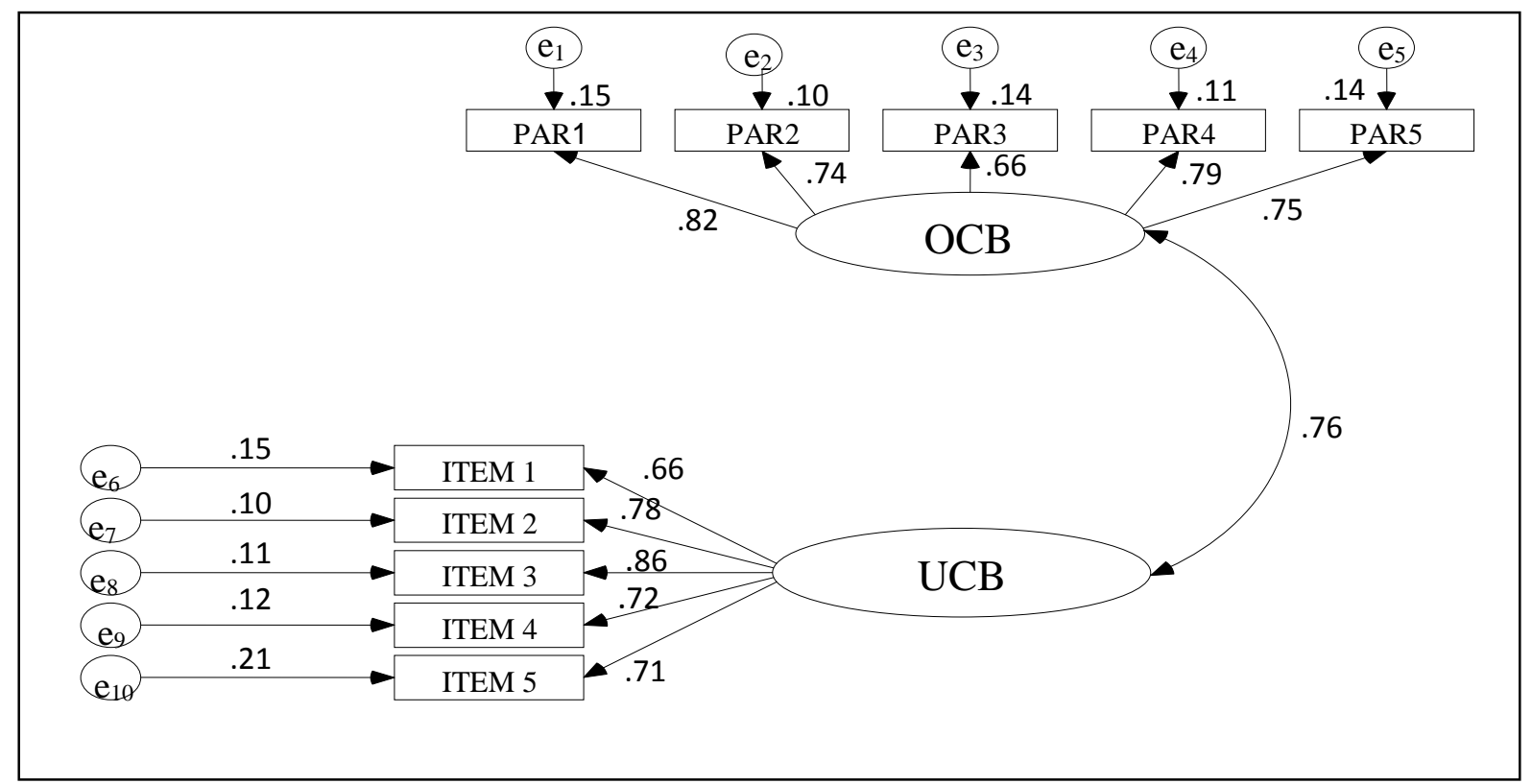

Fig 01: The model for Covariance between OCB and UCB

\section{Results}

The preliminary correlation analysis was carried out between the five dimension of OCB and UCB. The degree association between the five dimensions of OCB and UCB is shown in the following table.

Table 1: Correlation between Dimensions of OCB and UCB

\begin{tabular}{|l|l|l|l|l|l|}
\hline & Altruism & Conscientiousness & Courtesy & Sportsmanship & Civic Virtue \\
\hline UCB & .672 & .561 & .641 & .453 & .671 \\
& $\mathrm{P}=.000$ & $\mathrm{P}=.000$ & $\mathrm{P}=.000$ & $\mathrm{P}=.003$ & $\mathrm{P}=.000$ \\
\hline
\end{tabular}

*Significant at .01

According to the above table, it is indicative that all dimensions of OCB are positively and significantly correlated with UCB. Altruism and conscientiousness correlate with UCB at .672 and .561 value. The correlation between courtesy and civic virtue and UCB are .641 and .671. However, the OCB dimension of sportsmanship records a comparatively low level of association with UCB (.453). All these correlations are significant at .01 level of probability.

It is clearly evident that OCB and UCB can coexist in a unionized work environment. In other words, multilateral citizenship behavior is highly possible among the unionized employees. Therefore, a particular employee may exhibit both OCB and UCB in a unionized work environment. As a further examining the association between, OCB and UCB overall, the covariance between them was assessed. The model tested procedure estimated the covariance between $\mathrm{OCB}$ and $\mathrm{UCB}$ as aggregate variables. The estimated standard 
covariance is .76 as shown in the figure 01 . The covariance between OCB and UCB is positive and significant. It is an indication that OCB and UCB coexist in the unionized work context explored by this study.

It is intended to examine whether multilateral citizenship behavior varies across the level of unionization of the respondents. For this purpose, four categories of employee based on their union tenure period were identified (Less than one year, One to five years, Five to ten years and More than ten years. The base line model was tested among these four categories of respondents. The following figure and the table depict the model tested results.

Table II: Model fit Statistics across groups

\begin{tabular}{|l|l|l|l|l|l|}
\hline Union Category & $\boldsymbol{\chi 2}$ & Df. & $\boldsymbol{\chi 2} / \mathbf{D f}$ & CFI & RMSEA \\
\hline$>$ One year & 453,9 & 34 & 6.67 &, 901 & .069 \\
\hline One to Five Years & 432.1 & 34 & 6.35 & .921 & .070 \\
\hline Five to Ten Years & 392.2 & 34 & 5.77 & .933 & .072 \\
\hline$<$ Ten Years & 267.3 & 34 & 3.92 & .943 & .075 \\
\hline
\end{tabular}

As depicts in the above table, the model for multilateral citizenship behavior fitted best with the category of employees with more than ten years of union tenure $(\chi 2=267.3, d f=34$, $\mathrm{CFI}=.943$, RMSEA=.075,NFI=.945). The multilateral model fitted least with respondents with less than one year union tenure period tenure $(\chi 2=453.9, d f=34, \mathrm{CFI}=.901$, RMSEA=.069, NFI=.976). Further, it reveals that the model fit statistics improves when the union tenure of respondents increases. It is a clear indication that multilateral citizenship behavior is increasing among respondents when their union membership period increases.

\section{Conclusions}

The objective of this study is to examine whether the organizational citizenship behavior and union citizenship behavior coexists among unionized employees in Sri Lanka. It was initially found that there is a high and significant association between the two citizenship behaviors. That is an indication of the coexistence of organizational and union citizenship behavior among sampled employees. Further analysis indicated that this coexistence of OCB and UCB is more dominant among senior union member employees than junior member employees.

The findings of this study bear some significant managerial implications. First, the general perception of managers that unionized employees reduce their commitment and citizenship behavior towards the organization is challenged. This study proved that there is a possibility 
of having committed and dedicated set of employees though they are unionized. However, it seems that it doesn't materialize without an effort. Managers have to take some deliberate strategies so that they can still keep the OCB of employees in their organizations. For this, they have to design organization's Human Resources Management strategies such a way that it reveals employees that management is not militant with their union but rather corporative with them.

The finding of this study is bounded with some limitations. First, this study is based public sector organizations and was consisted of employees from selected number of public sector organizations. Therefore, the finding can be generalized to public sector organizations where employees are highly unionized like in Sri Lanka. Finally, data of this study was collected form employees themselves. Therefore, it is totally based on single source data. The multisource data may generate some different findings from the present study.

\section{References}

Aryee,S. \& Chey, Y.W. (2001). Workplace justice, citizenship behavior and turnover intention in a union context: Examining the mediating role of perceived union support and union instrumentality, Journal of Applied Psychology, 86(1), 154-160

Barling, J., Fullagar, C., \& Kelloway, E.K. (1992). The union and its members: A psychological approach, New York: Oxford University Press

Baterman, T.S. and Organ, D.W. (1983). Job satisfaction and the good soldier: The relationship between affect and employee citizenship, Academy of Management Journal, 26 (4) 587-595.

Chang, K., \& Chelladurai, P. (2003). Comparison of part-time workers and full-time workers: Commitment and citizenship behaviors in Korean sport organizations. Journal of Sport Management, 17(4), 394-416.

Mendoza,M.J.S. and Lara .P.Z.M. (2007)."The impact of work alienation on organizational citizenship behavior in the Canary Islands", International journal of organizational Analysis .15(1), 793-808.

Niehoff, B. P. and Moorman, R. H. (1993). Justice as a mediator of the relationship between monitoring and organizational citizenship behavior, Academy of Management Journal, $36,527-556$.

Organ, D. W. (1988). Organizational citizenship behavior: The good soldier syndrome. Lexington, MA: Lexington Books. 
Organ, D. W. (1990). The motivational base of organizational citizenship behavior, Research in Organizational Behavior, 12, $43-72$

Podsakoff, N., Whiting, S., Podsakoff, P., \& Blume, B. (2009). Individual- and organizational level consequences of organizational citizenship behaviors: A Metaanalysis. Journal of Applied Psychology, 94,122-141.

Podsakoff, P. M., \& MacKenzie, S. B. (1994). Organizational citizenship behaviors and sales unit effectiveness, Journal of Marketing Research,3, 351-363.

Skarlicki, D.P., and Latham, G.P. (1996). Increasing citizenship behavior within a labor union: a test of organizational justice theory, Journal of Applied Psychology,81,161-169,

Skarlicki, P.D. \& Lathem, P.G.(1996). Increasing citizenship behavior within a labor union: A test of organization justice theory, Journal of Applied Psychology, 81(2), 161-169

Snape, E. and Redman, T. (2004). Exchange or covenant: the nature of the member-union relationship, Industrial Relation, 43, 855-873

Twigg, W.N., Fuller, B.J. and Hester, K. (2008). Transformational leadership in labor organizations: The effect on union citizenship behavior, Journal of Labor Research, 29, $27-41$

Walz, S.\& Niehoff, B. (2000). Organizational citizenship behaviors: Their relationship to organizational effectiveness,Journal of Hospitality \& Tourism Research, 24, 108-126.

Williams, L.J. and Anderson, S.E. (1991). Job satisfaction and organizational commitment as predictors of organizational citizenship and in-role behavior, Journal of Management, $17(3)$ 601-657

Yen, H. R. and Niehoff, B. P. (2004). Organizational citizenship behaviors and organizational effectiveness: Examining relationships in Taiwanese banks, Journal of Applied Social Psychology, 34, 1617-1637. 